\title{
THE LARGE SCALE SOCIAL RESTRICTIONS POLICY FOR HANDLING THE COVID-19 PANDEMIC
}

\author{
Fradhana Putra Disantara \\ Universitas Negeri Surabaya \\ dfradhana@gmail.com
}

\begin{abstract}
This legal research uses a conceptual approach and a statutory approach. This research was carried out by inventorying primary and secondary materials, so as to obtain an appropriate analysis and critical review of published legal issues. The purpose of the study was to analyze the dynamics of Large Scale Social Restrictions Policies, especially regarding the Regulation of Minister of Health Number 9 of 2020and analyze various problematic PSBB policies during the pandemic. This study states that the PSBB is different from regional quarantine. On the other hand, the PSBB regulation in the Regulation of Minister of Health Number 9 of 2020 also raises doubts.Then, the Chief of Police's Declaration Mak/2/III/2020 provided strong legitimacy to strengthen the PSBB policy in terms of public compliance.The PSBB policy by the Central and Regional Governments has left various problems. Starting from material errors, contradiction of the article in the Governor's Regulation, and the Governor's Regulation which is not based on the Law above. The solution that can be done is to revise the Government Regulation No. 21 of 2020 and conduct executive review of the Governor's Regulation.
\end{abstract}

Keyword: Covid-19, Government Regulation, PSBB, Regulation of Minister of Health

\section{A. INTRODUCTION}

Determination of the public health emergency status through Presidential Decree (Keppres) No. 11 of 2020 on the Declaration of National Public Health Emergencygive the implications ofThe Large-Scale Social Restrictions / PembatasanSosialBerskalaBesar(PSBB) on a legal basis Government Regulation Number 21 Year 2020 on The Large-Scale Social Restrictions Of Accelerated Management of Covid-19. ${ }^{1}$ The PSBB policy is the 'best' and 'flexible' option. The PSBB policy is 'good' because the government's consideration pays attention to all aspects of community life, especially in terms of the community's economy.Meanwhile, the PSBB policy is a 'flexible' policy because it does not close the space for the community to carry out daily activities, especially various activities related to the primary needs of the community.

The PSBB policy aims to prevent the spread of the Corona Virus Desease 2019 (COVID-19) pandemic that occurs in a certain area. With the

1 Sufiarina and Sri Wahyuni, Force Majeure Dan Notoir Feiten Atas Kebijakan PSBB COVID-19, Jurnal Hukum Sasana, Vol. 6 No. 1 July , 2020. Page. 1-15 
existence of the PSBB policy, it is hoped that it can protect people from infection until the last case with a cooperative element from the community. The existence of a PSBB policy also prevents an area from becoming the epicenter of the spread of COVID-19. On the other hand, this restriction is also to prevent associations of people, both in small and large numbers. It must be understood that the PSBB Policy is implemented during the incubation period for a certain period of time. However, it is also possible that the PSBB could be extended again, taking into account indications of high-risk spread.

The implications of the PSBB policy are manifold, such as the consolation of all educational and work activities. ${ }^{2}$ However, these vacations are excluded for offices that are strategically positioned to be able to provide services. On the other hand, there are restrictions on some religious activities, and / or all activities carried out in public places or facilities, which also invite crowds. In fact, restrictions on transportation modes are treated by taking into account the number of passengers and maintaining the distance between passengers. So, it can be said that the PSBB policy is a shared responsibility to face a situation in a pandemic like this. $^{3}$

Practically,Government Regulation Number 21 Year 2020 on The Large-Scale Social Restrictions Of Accelerated Management of Covid-19is one of the response from government for the all problematic of legal certainty to all of district policy which is consedered to be illegal, it is kind of doing "lock down". Of course, Government Regulation (PP) Number 21 Year 2020leaves a problematic diversity.It is not only bureaucratic approach and the dominance of the center is too strong, it does not regulate the withdrawal of health care, ${ }^{4}$ and not only chooses not to look at the risk aspects of state financial expenditure, ${ }^{5}$ but Government Regulation No. 21 of 2020 experienced a material content error.

Even so, the existence of Government Regulation No. 21 of 2020 as formal legitimacy in handling COVID-19 technically has been carried out by several regions, no exception in East Java.As in East Java Governor Regulation No. 18 of 2020 concerning Large-Scale Social Limitation Guidelines in Handling Corona Virus Disease (COVID-19) in East Java Province (hereinafter referred to as Pergub East Java); which has been revised with East Java Governor Regulation No. 21 Year 2020. It was

2 Rindam Nasruddin and Islamul Haq, Pembatasan Sosial Berskala Besar (PSBB) Dan Masyarakat Berpenghasilan Rendah, SALAM: Jurnal Sosial dan Budaya Syar-i, Vol. 7 No. 7 May, 2020

3 Aprista Ristyawati, Efektifitas Kebijakan Pembatasan Sosial Berskala Besar Dalam Masa Pandemi Corona Virus 2019 Oleh Pemerintah Sesuai Amanat UUD NRI Tahun 1945, Administrative Law \& Governance Journal, Vol. 3 No. 2 Juni 2020,Page.240-249

4 Muh. Hasrul, Aspek Pemberlakuan Pembatasan Sosial Berskala Besar (PSBB) Dalam Rangka Penanganan Corona Virus Disease 2019 (COVID-2019), Legislatif, Vol. 3 No. 2 Juni 2020,Page.385-395

5 Susilawati Susilawati, Reinpal Falefi, and Agus Purwoko, Impact of COVID-19's Pandemic on the Economy of Indonesia, Budapest International Research and Critics Institute (BIRCIJournal): Humanities and Social Sciences, Vol. 3 No. 2 May 2020,Page.1147-1156 
explained that a number of areas in East Java Province especially in the cities / districts of Sidoarjo, Surabaya, and Gresik implemented the PSBB policy. However, problems arise in East Java Governor Regulation No. 18 of 2020jo East Java Governor Regulation No. 21 Year 2020 which does not base onLaw. No 24 Year 2007 on Disaster Management. In fact, Government Regulation No. 21 Year 2020 issued under Law No. 24 of 2007 on Disaster Management

There are several previous studies related to this research, including research entitled Analysis of Government Policy on Large Scale Social Restrictions in Handling Covid-19 by Ratna Desinta Mega Kumala (2020). The result of this research is the process of determining the PSBB in a region, it is feared that the PSBB will only be part of the policy, without uniform implementation in all regions. There is also another previous research, entitled Force Majeure and Notoir Feiten on the Policy on the PSBB COVID-19 which was researched by Sufiarina and Sri Wahyuni (2020). The results of the study is the Covid-19 PSBB was not automatically attached to all debtors but had to be personally proven to creditors. PSBB Covid-19 is a relative force majeure and results in a situation when the debtor's obligations can be collected again by the creditors. The two studies are different from research written by researchers at this time. The novelty of this research is to analyze the dynamics of the PSBB policy and its various problems. On the other hand, this research provides encouragement as a form of solution in dealing with various existing problems.

\section{B. RESEARCH METHODS}

The formulation of the problem in this research is how about the legal dynamics of the PSBB Policy ?, and what is the PSBB policy during the COVID-19 pandemic? The purpose of this study are analyze the dynamics of Large Scale Social Restrictions Policies, especially regarding the Regulation of Minister of Health Number 9 of 2020 and analyze various problematic PSBB policies during the COVID-19 pandemic. The approach method in this research uses the conceptual approach and the statue approach. ${ }^{6}$ This legal research uses primary legal materials, in the form of statutory regulations and secondary legal materials, in the form of legal publications including textual books, legal dictionaries, legal journals, and other legal literature.

\section{DISCUSSION}

\section{The Dynamics of Large-Scale Social Restrictions Policy}

PSBB has become the "best than the worst" solution, considering that there is a very high risk if the government chooses the Lockdown or Territorial Quarantine policy option. If we review the formulation of Article 55 of Law Number 6 of 2018, the implementation of regional

6 Fradhana Putra Disantara and Dicky Eko Prasetio, The Little Vatican: Optimalisisasi DWIPA (Desa Wisata Pancasila) Sebagai Upaya Meningkatkan Harmonisasi Sosial Dan Toleransi, Law, Development \& Justice Review, Vol. 3 No. 1 April 2020, Page.42-56 
quarantine raises the responsibility of the regional government and the central government to cover all the basic living needs of people and livestock food in the quarantine area. This formulation seems to be a heavy burden from the related government, considering that during the COVID-19 pandemic it causes bad economic turmoil. On this basis, the PSBB option was chosen by the government to break the chain of COVID-19. ${ }^{7}$

It must be understood that the concepts of PSBB and regional quarantine are different. ${ }^{8}$ PSBB is a limitation on certain activities of residents in an area suspected of being infected with Corona Virus Disease 2019 (COVID-19) in such a way as to prevent the possible spread of Corona Virus Disease 2019 (COVID-I9). Meanwhile, Territorial Quarantine is the restriction of the population in one area, including the area of entrance and its contents that are suspected of being infected with a disease and or contaminated in such a way as to prevent the possibility of spreading disease or contamination

Of course, the PSBB policy requires a formal legitimacy in the form of a Ministerial Regulation. Ministerial Regulation is a technical administrative regulation. Likewise with Regulationof MinisterofHealth Number 9of2020 on Guidelines to Large-scale Social Restrictions in Accelerating COVID-19 Mitigation,which regulates the PSBB. The implementation of the PSBB policy certainly has an impact on several line of life activities, for example the existence of school and work vacations, restrictions on religious activities, restrictions on social and cultural activities, restrictions on activities in public places or facilities, and so on.

The PSBB policy can be stipulated if there are a significant number of cases spreading simultaneously in an area. It must be understood that the PSBB policy to be established in a region is based on the request of the regional head to the Minister of Health. The submission of the PSBB application must be accompanied by various increases in the number of covid cases according to time (accompanied by an epidemiological curve), the spread of the pandemic according to time, there are local transmission events with the results of epidemiological investigations that state that second and third generation transmission has occurred. In addition, regional heads must attach data on regional readiness for health facilities or infrastructure, security aspects, budget and operationalization of social safety nets, availability of people's basic living needs.

However, several Local Governments had actualized the coverage of the PSBB policy prior to the issuance Regulationof MinisterofHealth Number 9of2020, especially in terms of school and work holidays and

7 Fradhana Putra Disantara, Aspek Imunitas Dalam Penanganan Corona Virus Disease 2019,Istinbath: Jurnal Hukum, Vol. 17 No. 1 Juni 2020,Page.65-82

8 Muhammad Wildan Ramdhani, Lockdown Policy As A Corona Desease (COVID-19) Management Efforts Asked From The Environmental Aspect of Life Based on Law Act No. 32 of 2009 Concerning Protection and Management of Environment, Veteran Law Review, Vol. 3 No. 1 May 2020, Page.22 
restrictions on social and cultural activities. Not only that, In fact, the local government through a Governor Regulation provides restrictions on activities in public places or facilities (such as hotels) to not accept guests who have certain symptoms of illness. ${ }^{9}$ However, it is strange if Regulationof MinisterofHealth Number 9of2020in fact provides exceptions in terms of limiting activities in public places or facilities, such as hotels.

Thus, there is a contradiction related to the legal orientation of the Regulationof MinisterofHealth Number 9of2020and the Governor Regulation. This phenomenon shows that local governments are more progressive, responsive, and uphold the moral consequences of the PSBB policy. On the other hand, the purpose of limiting various activities in public places is to encourage people to stay at home and implement social distancing / physical distancing ${ }^{10}$ Not only at the local government level, village communities in several districts and cities also responded to the PSBB policy very responsively. This response is reflected in the 'Local Lockdown' policy. This policy is carried out by closing the access roads in and out of the Village area using the portal.

In fact, the village government urges its residents not to leave the house if they do not do something very vital. The various village policies above were carried out in order to anticipate the potential spread of COVID-19 which is feared to be 'carried' by foreigners. In fact, the Indonesian National Police issued a binding instruction internally and externally with the issuance of the Chief of Police Declaration Mak/2/III/2020 concerning Compliance with Government Policies in Handling the Spread of COVID-19 on March 19, 2020. This decree was intended to take firm action against anyone which does not help prevent the spread of COVID-19. The basis for the publication of this edict is the principle of the Salus Populi Suprema Lex Esto or people's safety which is the highest law.

In principle, there are several important points in this Declaration, such as not holding social activities that cause mass gatherings, increasing the level of vigilance in their respective social environments, remaining calm and not panicking over the phenomenon of the COVID-19 virus, do not hoard related basic material needs or community needs, do not spread hoaxes that can cause unrest in the community. Of course, this edict encourages the public to continue implementing social and physical distancing in implementing various protocol policies that have been issued by the government. ${ }^{11}$ Even though

9 Fradhana Putra Disantara, The Validity of Rectors Circular Letter on the Covid-19 Pandemic, UNIFIKASI: Jurnal IImu Hukum, Vol. 7 No. 1 May 2020,Page.126

10 Ratna Desinta Mega Kumala, Legal Analysis of Government Policy on Large Scale Social Restrictions in Handling Covid-19, The Indonesian Journal of International Clinical Legal Education, Vol. 2 No. 2 2020, Page.181-200

11 Adlin and Ali Yusri, Penegakan Hukum Pemerintahan: Kekuasaan Walikota Pekanbaru Memberlakukan Beleidsregels Guna Memutus Penyebaran Virus Covid-19 Di Kota Pekanbaru, Jurnal IImiah Muqoddimah, Vol. 4 No. 2 2020, Page.71-81 
the edict only contains the meaning of notification to the general public, but it is related to the law, it has binding power.

So that no doubt there are criminal threats to the community that obstruct the prevention of the Covid-19 outbreak as an action of the presence of the Chief of Police's Declaration Mak/2/III/2020, among others regulated in: (a) Article 14 Paragraph (1) and (2) of the Law Number 4 of 1984 concerning Communicable Disease Outbreaks; (b) Article 93 of Law Number 6 of 2018 concerning Health Quarantine; (c) Articles 212, 214, 216 Paragraph (1), and 218 of the Criminal Code (KUHP). In practice, the substance of the announcement above strengthens the legitimacy and urgency of the 'restriction' policy in the implementation of the PSBB.

The presence of Regulationof MinisterofHealth Number 9of2020has become the legal basis for the implementation of the PSBB policy by various local governments. The public's hope that the PSBB policy would be separated from the "bureaucratic approach" has also caused problems.

If we review the formulation of Article 7 Paragraph 4 of the Regulationof MinisterofHealth Number 9of2020, the PSBB Policy is determined by a team formed by the Minister of Health within a grace period of 1 day, no later than the receipt of the request for determination. Of course, this formula is just like a pro forma requirement. In fact, the scope of epidemiological studies as well as various economic, political, social, cultural, religious, defense and security aspects requires a fairly detailed dimension of understanding and elaboration. Determination of policies during the PSBB within a maximum period of one day, would raise doubts among the general public considering the occurrence of several 'unfavorable phenomena' in resolving this pandemic problem, the slow PCR or SWAB examination results,confusing news regarding the number of COVID-19 victims, and others. How much better, the team manages and analyzes related data studies submitted by various regional heads regarding the submission of PSBB applications in accordance with the formulation of Article 4 Paragraph 1 of the Regulationof MinisterofHealth Number 9of2020.

Meanwhile, the PSBB policy certainly does not release the government's responsibility to continue to optimize the fulfillment of the needs of the people living in the PSBB area. If it is related to the COVID19 Pandemic, the government must really carry out the mandate of Article $28 \mathrm{H}$ paragraph 1 of the 1945 Constitution of Indonesia which reads "Everyone has the right to live in physical and mental prosperity, to live, and to have a good and healthy living environment and the right to obtain services. health". Fulfilling human rights related to health services is a very primary thing for the government to do. ${ }^{12}$ This is because government policies have large excesses in various community

12 Fradhana Putra Disantara and Dicky Eko Prasetio, "Nalar Hagemonik Perppu COVID-19," Gresnews.Com, last modified 2020, accessed April 1, 2020, http://www.gresnews.com/berita/opini/117983-nalar-hagemonik-perppu-covid-19/. 
activities related to health services as well. With regard to the health condition, it will be a very important part considering that human survival is related to health conditions both psychologically and physically.

\section{Variety of Problems of Large Scale Social Limitation}

Enforcement of policies in the perspective of state emergency law can be distinguished between emergency de jure and emergency de facto. $^{13}$ Of course, de facto or de jure emergencies have logical consequences for the rule of law. Essentially, PSBB is included in the actualization category of emergency de jure. This is based on an official statement from the government represented by President Joko Widodo who said he was providing public health emergency status. In addition, emergency de jure can provide orientation to certain limitations to the community, so the emergency paradigm leaves entirely totalitarian and repressive aspects. Enforcement of emergency legal status with an emergency de jure classification can provide protection for the human rights of citizens who are experiencing an emergency.

We already know PSBB is a limitation of certain activities for residents in an area that is suspected to have been infected or has been infected with COVID-19. Related to social distancing and physical distancing (PSBB) guidelines, it has been stipulated in Regulation of Minister of Health Number 9 of 2020 on Guidelines to Large-scale Social Restrictions in Accelerating COVID-19 Mitigation. Regulation of the Minister of Health Number 9 of 2020 on Guidelines to Large-scale Social Restrictions in Accelerating COVID-19 Mitigation can be said to be quite detailed in regulating activities that are closed, restricted, and excluded from restrictions during the PSBB period. With the Regulation of the Minister of Health Number 9 of 2020 on Guidelines to Large-scale Social Restrictions in Accelerating COVID-19 Mitigation, the Regional Government must implement all the provisions contained in the Regulation of the Minister of Health Number 9 of 2020 on Guidelines to Large- scale Social Restrictions in Accelerating COVID-19 Mitigation.

First, If reviewed from Law No 12 Year 2011 jo Law No 15 Year 2019 on concerning Formation of Legislation, the existence of Government Regulation No. 21 Year 2020 is at the technical constitution, namely as the Implementing Regulations of a law. Government Regulation has two cumulative conditions that will fulfill the validity of the Government Regulation. ${ }^{14}$ First, the Government Regulation must be made by institutions outside the legislative or government organ. Second, Government Regulation must be derived from a law (UndangUndang), so it can be said that Government Regulation was made because there are laws that govern, so that Government Regulation was made. When viewed from the part of 'remember' (mengingat) on

13 Alan Greene, Permanent States of Emergency and the Rule of Law: Constitutions in an Age of Crisis, Bloomsbury Publishing, New York, 2018

14 Asri Muhammad Saleh and Wira Atma Hajri, Perihal Pengujian Peraturan Pemerintah Pengganti Undang-Undang, Deepublish, Sleman, 2018, Page.55 
Government Regulation No. 21 Year 2020, Government Regulation No. 21 Year 2020 does not provision of any particular law.

Second, Hananto Widodo said, ${ }^{15}$ if we look at Article 10 Section (4) of Law No. 6 of 2018, we can make sure that there are material content errors. Because of that, Article 10 Section (4) of Law No. 6 of 2018 regulates the procedures for the determination and revocation of health emergencies, not regulating the handling of the COVID-19 pandemic.Practically, it could be called 'inverse logic', which is that a Presidential Decree is first issued to establish an emergency, then the new rules (PP No 21 Year 2020) appear.Supposedly, if we look at Article 5 Section (2) of the Constitution of the Republic of Indonesia 1945 which states that 'The President may issue Government regulations as required to implement laws', Government Regulation No. 21 Year 2020 is used as the basis for the issuance of Keppres, not PP No. 21 of 2020 published based on the Presidential Decree. Presidential Decree is the 'closing norm' that becomes the norm of stipulation or what we commonly call 'beschikking'. Even though a Presidential Decree is issued by a public official who is binding on the entire community, it is a closed norm. Thus, the Presidential Decree cannot be used as the basis for the issuance of PP No. 21 Year 2020. Supposedly, PP No. 21 of 2020 issued based on Article 10 of Law Number 6 of 2018 regulating the procedures and conditions for declared health emergency status.

Third, Haidar Adam said that the PSBB option can be seen from the aspect of legal effectiveness, ${ }^{16}$ namely from the aspect of formulating legal norms, implementing institutions, the legal culture of the community. ${ }^{17}$ From the legal normas, there is no government obligation to guarantee the public life, and there is a very wide space of discretion which makes law enforcers implement various interpretations of it. Furthermore, there was no binding penalty sanctions for violators, and these regulations were very difficult to enforce.On the other hand, the relaxation of sanctions contained in PP No 21 Year 2020 is very vulnerable to lead to potential abuse of bureaucratic authority. From the institutional aspect in which it is observed, PSBB policies are varying from region to region, with different regional policies. Furthermore, from cultural aspects of the law, the consciousness of society was still quite low, so obedience to established laws was regarded as a mere formative

15 Helmi Supriyatno, "Kepastian Hukum Darurat Kesehatan," Harianbhirawa.Co.Id, last modified, accessed April 6, 2020. https://www.harianbhirawa.co.id/kepastian-hukumdarurat-kesehatan/

16 Haidar Adam, "Menyoal Efektivitas Pemberlakuan PSBB Di Jawa Timur," Telusur.Co.Id, last modified 2020, accessed April 7, 2020, https://www.telusur.co.id/detail/menyoalefektivitas-pemberlakuan-psbb.

17 Mauro Zamboni, Legislative Policy and Effectiveness: A (Small) Contribution from Legal Theory, European Journal of Risk Regulation, Vol. 9 No. 3 September 2018, Page.416-430 
symbol, and was not followed by behavior consistent with the rules. Low awareness is what can cause massive spread of COVID-19. ${ }^{18}$

The urgency of law enforcement must be taken if various appeals are not obeyed by the community. In fact, the obedience of society will depend on the safety of the community itself. The fundamental weakness of the PSBB is that it relies too much on public legal awareness. Meanwhile, a few months ago, almost every day we listened to the news stating that a large number of people had violated the PSBB. However, the primary step that must be taken is to build public awareness to comply with the PSBB policy.

In fact, the formulation of Article 93 of Law Number 6 of 2018 has provided provisions for criminal sanctions for violators of health quarantine activities with a maximum imprisonment of one year and a maximum fine of one hundred million rupiah. Even, it is possible that the primum remedium principle is an extraordinary effort in a certain period of time (emergency). Thus, the application of criminal sanctions can be prioritized in order to provide a deterrent effect to violators of existing regulations. On the other hand, the application of the principle of primum remedium in times of emergency becomes the element of protection of the soul or life of the community. The community must be given education; that the current situation encourages the community to become a "frontier" to ward off the spread of COVID-19. This is what builds legal awareness that will lead to law obedience for the community. Public awareness and obedience to the law is a moral responsibility to bring up human values that balance the negative impacts of COVID-19.

Fourth. The application of PSBB who has regulated in East Java Governor Regulation No. 18 Year 2020 jo East Java Governor Regulation No. 21 Year 2020, they are unmet by the principles of the rule of law. There is a contradiction in Article 18 Section (1) East Java Governor Regulation No. 18 Year 2020 jo East Java Governor Regulation No. 21 Year 2020 (hereinafter referred to as East Java Governor Regulation PSBB) which is 'in conflict' with Article 18 Section (2) and Article 18 Section (3) East Java Governor Regulation PSBB. In Article 18 Section (1) East Java Governor Regulation PSBB explained that during the implementation of PSBB, a temporary shutdown of all activities of persons and or things was observed. Article 18 Section (1) East Java Governor RegulationPSBB only allows for the movement of people and/or items that haveto do with meeting basic needs, other activities especially in defense and security aspects, and activities that are permitted during the establishment of the PSBB. However, this Article raises a contradiction with Article 18 Section (2) East Java Governor RegulationPSBB, which allows the movement of people who use the type of mode of private motor transportation, public motor vehicles, railroads, and river, lake and crossing transportation. Then, the contradiction in

18 Yongshi Yang et al., The Deadly Coronaviruses: The 2003 SARS Pandemic and the 2020 Novel Coronavirus Epidemic in China, Journal of Autoimmunity, Vol. 109 No. - May 2020, Page. 102434 
this Article 18 East Java Governor PSBB is especially 'bright' when Articles 18 Section (3) East Java Governor Regulation PSBB regulate the exclusion of stopping the movement of goods for all types of modes of transportation. Of course, it can be concluded that Article 18 Section (1) East Java Governor Regulation PSBB 'contrary' to Article 18 Section (2) and Section (3) East Java Governor Regulation PSBB.

Fifth, East Java Governor Regulation No. 18 of 2020jo East Java Governor Regulation No. 21 Year 2020 which does not base onLaw. No 24 Year 2007 on Disaster Management. In fact, PP No. 21 Year 2020 issued under Law No. 24 of 2007 on Disaster Management. Of course, this phenomenon can be said that the East Java Governor Regulation PSBB is 'legally flawed'. If reviewed in the ordinance of legislation as regulated by Law No. 12 Year 2011 jo Law No. 15 Year 2019 on concerning Formation of Legislation, the East Java Governor Regulation PSBB should be based on Law No. 24 of 2007 on Disaster Management. By not mentioning the Law No. 24 of 2007 on Disaster Management, the East Java Governor Regulation PSBB has disaligned with the stufenbau theory. In fact, that the validity of a regulation must be adjusted to the existing theory. One theory used in the formation of a regulation is stufenbau theory, that the validity of a norm is based on a hierarchy of norms, so it is layered and steeped, or by higher rules. Based on the stufenbau theory, a legal system has pyramid structures, ranging from the most abstract to the most concrete. ${ }^{19}$ This impels a legal system to have a pyramid structure, ranging from the most abstract to the most concrete. ${ }^{20}$ In addition to the norms layer and tiered layer, the legal norms of a country are also in groups. ${ }^{21}$ Hans nawiaski states a legal norm of any country is layed and steeped. ${ }^{22}$ The norms below are valid, sourced and based on higher norms, called Basic Norms. In this theory, a legal system is brought into existence by all other laws and rules made and enacted under the rule of power that is directly or indirectly given by basic norms. ${ }^{23}$ The norms below are valid, sourced and based on higher norms, which are called basic norms.. ${ }^{24}$

Then, Hans Nawisaky states that the legal norms of a country are in groups, and the grouping of legal norms in a country consists ofStaatsfundamentalnorm, Staatsgrundgesetz, Formell Gesetz, Verordnung\& Autonome Satzung. ${ }^{25}$ The four classifications of norm groups can be ensured always exist in a country's legal system which in principle the number of legal norms and legislation in each country is

19 Hans Kelsen, The Pure Theory of Law and Analytical Jurisprudence, Harvard Law Review 1941, Page. 11

20 Hans Kelsen, General Theory of Law and State, The Lawbook Exchange, New Jersey, 1999, Page. 8

21 Hans Kelsen, On The Pure Theory of Law, Israel Law Review, Vol. 1 No. 1 January 1966, Page.1-7

22 Ibid.

23 Hans Kelsen, On the Basic Norm, California Law Review, 1959, Page.17

24 Joseph Raz, The Identity of Legal Systems, California Law Review, 1971, Page.9

25 Kelsen, General Theory of Law and State. 
very different. ${ }^{26}$ Staatsfundamentalnormis the highest norm, or can be called a fundamental norm for a country. ${ }^{27}$ Fundamental norms of the state are a form of reflection of the ideals of society in a country, which has been established by the community as well, into a type of norm that is not formed by a higher norm. ${ }^{28}$ Fundamental norms of the state can also be referred to as a norm on which to 'depend' (basis and legitimacy) from the legal norms below. ${ }^{29}$ Staatsfundamentalnormhas become the basis for the philosophy of the establishment of Staatsgrundgesetz. ${ }^{30}$

Staatsgrundgesetz can be referred to as the basic rules of a country which has the character of a single norm and as an outline of the norms it derives. ${ }^{31}$ Then, Staatsgrundgesetzcan be stated in a stateowned document, or commonly calledstaatsverfassung. ${ }^{32}$ The hierarchy of norms in Indonesia can be reviewed in No. 12 Year 2011 jo Law No. 15 Year 2019 on concerning Formation of Legislation which includes :

a. The Constitution of the Republic of Indonesia 1945;

b. The MPR's Decree;

c. Law/PeraturanGovernment Regulation in Lieu of Law;

d. Government Regulation;

e. PeraturanPresiden;

f. Presidential Regulation;

g. Provincial Regulation;

h. Regency or Municipality Regulation.

For this reason, a legal norm is derived from above and becomes the source of the legal norms below. ${ }^{33}$ When the norms of the above provisions are removed, they are uprooted and even deleted. ${ }^{34}$ So, according to stufenbautheory, the East Java Governor Regulation PSBB experiences a disharmony with the laws and regulations above it, namely Law No. 24 of 2007 on Disaster Management. In addition, the East Java Governor Regulation PSBB has the potential to conflict with the legal principle which reads/ex superior derogate legi inferior.

26 A. Hamid S. Attamimi, Ilmu Pengetahuan Perundang-Undangan Dan Pengembangan Pengajarannya Di Fakultas Hukum, Jurnal Hukum \& Pembangunan, Vol. 20 No. 1 February 1990, Page. 1

27 Ibid.

28 A. Hamid S. Attamimi, Materi Muatan Perpu, Jurnal Hukum \& Pembangunan, Vol. 9 No. 3 June 1979, Page. 281

29 Attamimi, Ilmu Pengetahuan Perundang-Undangan Dan Pengembangan Pengajarannya Di Fakultas Hukum, Jurnal Hukum \& Pembangunan, Volume 20, No. 1, February1990

30 Kelsen, General Theory of Law and State.

31 Retno - Saraswati, Problematika Hukum Undang-Undang No.12 Tahun 2011 Tentang Pembentukan Peraturan Perundang-Undangan, Yustisia Jurnal Hukum Vol. 2 No. 3 September 2013, Page.99

32 Kelsen, On the Basic Norm, California Law Review, 1959.

33 Adolf Merkl, Prolegomena Einer Theorie Des Rechtlichen Stufenbaues, Gesellschaft · Staat Und Recht, Vienna, Springer Vienna, 1931, Page.252-294

34 Martin Borowski, Concretized Norm and Sanction qua Fact in the Vienna School's Stufenbaulehre, Ratio Juris, Vol. 27 No. 1 March 2014, Page.79-93 


\section{CONCLUSION}

PSBB as the "best than worst" option has differences with regional quarantine. However, PSBB raises various implications; which in principle provides restrictions on various community activities. In terms of technical matters, the PSBB has been regulated by the Regulation of Minister of Health Number 9 of 2020. On the other hand, the legitimacy of the PSBB is strengthened by the Chief of Police's Declaration Mak / 2 / III / 2020. However, doubts arise regarding the determination of the PSBB policy which is regulated in the Regulation of the Minister of Health Number 9 of 2020.

In dealing with this problem, the team formed by the minister of health should focus more on analyzing the data provided by each regional head who plans to determine PSBB in their regional areas. The PSSB option as a policy of the central or regional government in implementing COVID-19 leaves a variety of problems. First, PP No. 21 of 2020 does not include the provisions of which law. Second, the basis for the issuance of PP No. 21 of 2020 not from Law Number 6 of 2018, but is issued by the Presidential Decree. Third, seen from the aspect of legal effectiveness, the implementation of the PSBB policy does not yet reflect the legal effectiveness. Fourth, there is a contradiction between Article 18 Section (1) and Article 18 Section (2) and (3) Governor Regulation No. 18 of 2020 jo Regulation of the Governor of East Java No. 21 of 2020. Fifth, Governor Regulation No. 18 of 2020 jo Regulation of the Governor of East Java No. 21 of 2020 does not base itself on the above regulations, i.e Law No. 24 of 2007 on Disaster Management. The solution suggested by researchers is to revise PP No. 21 of 2020 and Governor Regulation No. 18 of 2020 jo Regulation of the Governor of East Java No. 21 of 2020, conduct an executive review for Governor Regulation No. 18 of 2020 jo Regulation of the Governor of East Java No. 21 of 2020, massive socialization of PSSB policies

\section{BIBLIOGRAPHY}

\section{Books}

Greene, Alan, 2018, Permanent States of Emergency and the Rule of Law: Constitutions in an Age of Crisis, Bloomsbury Publishing, New York;

Kelsen, Hans, 1999, General Theory of Law and State, The Lawbook Exchange, New Jersey;

Merkl, Adolf, 1931, Prolegomena Einer Theorie Des Rechtlichen Stufenbaues, In Gesellschaft Staat Und Recht, Vienna: Springer Vienna;

Saleh, Asri Muhammad, and Wira Atma Hajri, 2018, Perihal Pengujian Peraturan Pemerintah Pengganti Undang-Undang, Deepublish, Sleman; 


\section{Journals}

Adlin, and Ali Yusri, Penegakan Hukum Pemerintahan: Kekuasaan Walikota Pekanbaru Memberlakukan Beleidsregels Guna Memutus Penyebaran Virus Covid-19 Di Kota Pekanbaru, Jurnal IImiah Muqoddimah, Volume 4, No. 2, 2020;

Attamimi, A. Hamid S, Ilmu Pengetahuan Perundang-Undangan Dan Pengembangan Pengajarannya Di Fakultas Hukum, Jurnal Hukum \& Pembangunan, Volume 20, No. 1, February 1990;

- Materi Muatan Perpu, Jurnal Hukum \& Pembangunan, Volume 9, No. 3, June 1979;

Borowski, Martin, Concretized Norm and Sanction qua Fact in the Vienna School's Stufenbaulehre, Ratio Juris, Volume 27, No. 1, March 2014;

Disantara, Fradhana Putra,Aspek Imunitas Dalam Penanganan Corona Virus Disease 2019, Istinbath: Jurnal Hukum, Volume 17, No. 1, Juni 2020;

- The Validity of Rectors Circular Letter on the Covid-19 Pandemic, UNIFIKASI: Jurnal IImu Hukum, Volume 7, No. 1, May 2020;

— The Little Vatican: Optimalisisasi DWIPA (Desa Wisata Pancasila) Sebagai Upaya Meningkatkan Harmonisasi Sosial Dan Toleransi, Law, Development \& Justice Review, Volume 3, No. 1, April 2020;

Hasrul, Muh., Aspek Pemberlakuan Pembatasan Sosial Berskala Besar (PSBB) Dalam Rangka Penanganan Corona Virus Disease 2019 (COVID2019), Legislatif, Volume, 3, No. 2, 2020;

Kelsen, Hans. On the Basic Norm. California Law Review, 1959;

- On The Pure Theory of Law, Israel Law Review, Volume 1, No. 1, January 1966;

- The Pure Theory of Law and Analytical Jurisprudence, Harvard Law Review, 1941;

Kumala, Ratna Desinta Mega, Legal Analysis of Government Policy on Large Scale Social Restrictions in Handling Covid-19, The Indonesian Journal of International Clinical Legal Education, Volume 2, No. 2, 2020;

Nasruddin, Rindam, and Islamul Haq, Pembatasan Sosial Berskala Besar (PSBB) Dan Masyarakat Berpenghasilan Rendah, SALAM: Jurnal Sosial dan Budaya Syar-I, Volume 7, No. 7, May 2020;

Ramdhani, Muhammad Wildan, Lockdown Policy As A Corona Desease (COVID19) Management Efforts Asked From The Environmental Aspect of Life Based on Law Act No. 32 of 2009 Concerning Protection and Management of Environment, Veteran Law Review, Volume 3, No. 1, May 2020; 
Raz, Joseph, The Identity of Legal Systems, California Law Review, 1971;

Ristyawati, Aprista, Efektifitas Kebijakan Pembatasan Sosial Berskala Besar Dalam Masa Pandemi Corona Virus 2019 Oleh Pemerintah Sesuai Amanat UUD NRI Tahun 1945, Administrative Law \& Governance Journal, Volume3, No. 2, 2020;

Saraswati, Retno, Problematika Hukum Undang-Undang No.12 Tahun 2011 Tentang Pembentukan Peraturan Perundang-Undangan, Yustisia Jurnal Hukum, Volume 2, No. 3, September2013;

Sufiarina, and Sri Wahyuni, Force Majeure Dan Notoir Feiten Atas Kebijakan PSBB COVID-19, Jurnal Hukum Sasana, Volume 6, No. 1 July 2020;

Susilawati, Susilawati, Reinpal Falefi, and Agus Purwoko, Impact of COVID-19's Pandemic on the Economy of Indonesia, Budapest International Research and Critics Institute (BIRCI-Journal):Humanities and Social Sciences, Volume 3, No. 2, May 2020;

Yang, Yongshi, Fujun Peng, Runsheng Wang, Kai Guan, Taijiao Jiang, Guogang $\mathrm{Xu}$, Jinlyu Sun, and Christopher Chang, The Deadly Coronaviruses: The 2003 SARS Pandemic and the 2020 Novel Coronavirus Epidemic in China, Journal of Autoimmunity, 2020;

Zamboni, Mauro, Legislative Policy and Effectiveness: A (Small) Contribution from Legal Theory, European Journal of Risk Regulation, Volume 9, No. 3, September 2018;

Website

Adam, Haidar. Menyoal Efektivitas Pemberlakuan PSBB Di Jawa Timur. Telusur.Co.Id. Last modified 2020. Accessed April 7, 2020. https://www.telusur.co.id/detail/menyoal-efektivitaspemberlakuan-psbb;

Disantara, Fradhana Putra, and Dicky Eko Prasetio. Nalar Hagemonik Perppu COVID-19. Gresnews.Com. Last modified 2020. Accessed April 1, 2020. http://www.gresnews.com/berita/opini/117983-nalarhagemonik-perppu-covid-19/;

Supriyatno, Helmi. Kepastian Hukum Darurat Kesehatan. Harianbhirawa.Co.Id.Accessed April 6, 2020.https://www.harianbhirawa.co.id/kepastian-hukumdarurat-kesehatan/. 